\title{
Environmental quality assessment of groundwater resources in Al Jabal Al Akhdar, Sultanate of Oman
}

\author{
Mohammed Saif Al-Kalbani ${ }^{1} \cdot$ Martin F. Price ${ }^{2} \cdot$ Mushtaque Ahmed $^{3}$ • \\ Asma Abahussain ${ }^{4} \cdot$ Timothy O'Higgins ${ }^{5}$
}

Received: 2 February 2015/ Accepted: 11 September 2017/Published online: 30 September 2017

(c) The Author(s) 2017. This article is an open access publication

\begin{abstract}
The research was conducted to assess the quality of groundwater resources of Al Jabal Al Akhdar, Oman. 11 drinking water sources were sampled during summer and winter seasons during 2012-2013 to evaluate their physicochemical quality indicators; and assess their suitability for drinking and other domestic purposes. Sample collection, handling and processing followed the standard methods recommended by APHA and analyzed in quality assured laboratories using appropriate analytical methods and instrumental techniques. The results show that the quality
\end{abstract}

Mohammed Saif Al-Kalbani

Kmohd2020@yahoo.com

Martin F. Price

Martin.Price.perth@uhi.ac.uk

Mushtaque Ahmed

ahmedm@squ.edu.om

Asma Abahussain

asma@agu.edu.bh

Timothy O'Higgins

tim.ohiggins@ucc.ie

1 Ministry of Environment and Climate Affaires,

P. O. Box 323, PC 100 Muscat, Sultanate of Oman

2 Centre for Mountain Studies, Perth College, University of the Highlands and Islands, Crieff Road, Perth PH1 2NX, UK

3 Department of Soils, Water and Agricultural Engineering, College of Agricultural and Marine Sciences, Sultan Qaboos University, P. O. Box 34, Al-Khod, 123 Muscat, Sultanate of Oman

4 Department of Natural Resources and Environment, College of Graduate Studies, Arabian Gulf University, Manama 26671, Kingdom of Bahrain

5 Environmental Research Institute, University College Cork, Beaufort Building, Haulbowline Road, Ringaskiddy, Co. Cork, Ireland parameters in all drinking water resources are within the permissible limits set by Omani and WHO standards; and the drinking water quality index is good or medium in quality based on NFS-WQI classification criteria, indicating their suitability for human consumption. There is an indication of the presence of high nitrate concentrations in some groundwater wells, which require more investigations and monitoring program to be conducted on regular basis to ensure good quality water supply for the residents in the mountain. The trilinear Piper diagram shows that most of the drinking water resources of the study area fall in the field of calcium and bicarbonate type with some magnesium bicarbonate type indicating that most of the major ions are natural in origin due to the geology of the region. This study is a first step towards providing indicators on groundwater quality of this fragile mountain ecosystem, which will be the basis for future planning decisions on corrective demand management measures to protect groundwater resources of $\mathrm{Al} \mathrm{Jabal} \mathrm{Al}$ Akhdar.

Keywords Groundwater · Piper trilinear diagram - Water quality index · Hydrochemistry - Al Jabal Al Akhdar .

Oman

\section{Introduction}

Groundwater resources-from boreholes, hand-dug wells and springs (Anudu et al. 2011; Al-Khashman and Jaradat 2014)-play a significant role in arid and semi-arid regions, where they are the main sources of freshwater for drinking, agriculture and other domestic purposes. Due to rapid increase in population and urbanization, and associated anthropogenic activities, in these regions, their groundwater resources are prone to pollution from different 
sources (Khattak et al. 2012; Kata et al. 2014; Li et al. 2014). This leads to poor drinking quality, high cleanup costs, loss of water supply and high costs for alternative water supplies and may cause potential health problems (Adhikary et al. 2012; Duan et al. 2014; Huang et al. 2014).

Like its quantity, the quality of water is of great importance in the planning and management of water supplies; this must be supported by water quality monitoring and assessment. If not properly managed, water quality can be a serious limiting factor to economic development and public health, which may result in enormous long-term costs to society (Sadat-Noori et al. 2014; Nasrabadi and Abbasi Maedeh 2014). Water quality is primarily governed by the extent and composition of dissolved solids (Tomar et al. 2012; Huang et al. 2014) and is a function of physico-chemical parameters, influenced by natural and anthropogenic factors including local climate, geology and human activities (Tatawat and Chandel 2008; Al-Harbi et al. 2014; Gueroui et al. 2014). The hydrochemical characteristics of groundwater determine its quality and suitability for drinking and other uses, and may also vary seasonally.

Generally, the movement of groundwater along its flow paths increases chemical concentrations (Kortatsi 2007; Khashogji and El Maghraby 2013; El Maghraby et al. 2013). Hence, its chemistry can reveal important information on the geological history of the aquifers, the degree of chemical weathering of various rock types, quality of recharge water and inputs from sources other than water rock interactions (Aghazadeh and Mogaddam 2011; AlKhashman and Jaradat 2014). Several studies have tried to investigate the hydro-chemical facies and water type in order to provide preliminary information about the complex hydro-chemical processes in groundwater (e.g., Tatawat and Chandel 2008; Chowdhury and Gupta 2011; Samanta et al. 2013; Ewusi and Kuma 2014). A number of techniques and methods have been developed to interpret the hydro-chemical data of groundwater and evaluate its suitability for drinking by interpreting the analyses of water quality and illustrating its characteristics on maps (SadatNoori et al. 2014; Magesh et al. 2013). Some of these techniques (e.g., Piper 1944; Gibbs 1970; Wilcox 1955; Doneen 1964; Chadha 1999) can present such analyses in graphical form and have been used in many parts of the world including arid and semi-arid regions (Kortatsi et al. 2009; Ayuba et al. 2013; Aly et al. 2014; Nazzal et al. 2014; Kraiem et al. 2014) to show ionic concentrations in groundwater samples.

This study interprets and classifies the hydro-chemical quality of groundwater resources in $\mathrm{Al} \mathrm{Jabal} \mathrm{Al} \mathrm{Akhdar,}$ Sultanate of Oman, and evaluates their suitability for drinking. No such study has previously been conducted in this fragile mountainous region. Because of its strategic and military importance, access to the area was prohibited until recently. Previous studies on water quality (e.g., AlUjaili 1997; Victor and Al-Ujaili 1998, 1999; Al-Haddabi 2003; Ahmed et al. 2006; Jashoul 2008; Al-Haddabi et al. 2009; Victor et al. 2009) focused only on the area's dams and aflaj (irrigation channels). This paper presents a comprehensive assessment of the quality of the government water supply from groundwater aquifers, the only available resources for drinking and domestic consumption in $\mathrm{Al}$ Jabal Al Akhdar. It focuses on the physico-chemical characteristics of groundwater resources in the area, investigates the mechanisms controlling groundwater composition, and provides an environmental assessment on drinking water quality indices.

\section{Regional and hydrogeological setting}

Al Jabal Al Akhdar (Green Mountain) forms the central part of the northern mountains of the Sultanate of Oman (Fig. 1), with altitudes from 1500 to $3000 \mathrm{~m}$ above sea level (Dorvlo et al. 2009). The area of Al Jabal Al Akhdar is not exactly identified or formally designated. According to Ashura Council (2010), the whole area of the mountain is estimated at approximately $2600 \mathrm{~km}^{2}$. The extent area addressed by this study is Niyabat Al Jabal Al Akhdar, which is $404 \mathrm{~km}^{2}$ (Al-Mukhtar 2013). In this area, temperatures drop during winter to below $0{ }^{\circ} \mathrm{C}$ and rise in summer to $22{ }^{\circ} \mathrm{C}$, and the annual mean rainfall $(300-400 \mathrm{~mm})$ is higher than on the desert plains (DGMAN 2014). Due to its location and unique weather, the Green Mountain produces a variety of perennial fruits, especially pomegranates, and roses.

The geology of Al Jabal Al Akhdar consists of tectonically emplaced late Paleozoic and Mesozoic continental margin and Tethyan deep sea sediments along with a slab of Cretaceous oceanic crust and mantle: the Samail ophiolites (Glennie et al. 1974; Stanger 1986). They include the oldest rocks in the area: phyllites, mudstones, limestones and meta-volcanics (Al-Fahdi 2011). The limbs of the anticline are formed by rocks of the Hajar Super Group, a sequence of shallow marine carbonates which were laid down unconformably on the pre-Permian basement between the Permian and Cretaceous periods (Hanna 1995). The rocks consist of relatively uniform dark gray crystalline limestones and dolomitic limestones with abundant corals, gastropods, and bivalves. Thin yellow and pink siltstones occur throughout the sequence. The prePermian formations consist of a wide variety of rock types including green, maroon and pale yellow slates, tan and gray limestones and conglomerates (Glennie 2005).

The Hajar Super Group is the most important carbonate rock aquifer of northern Oman's Mountains. The carbonate 


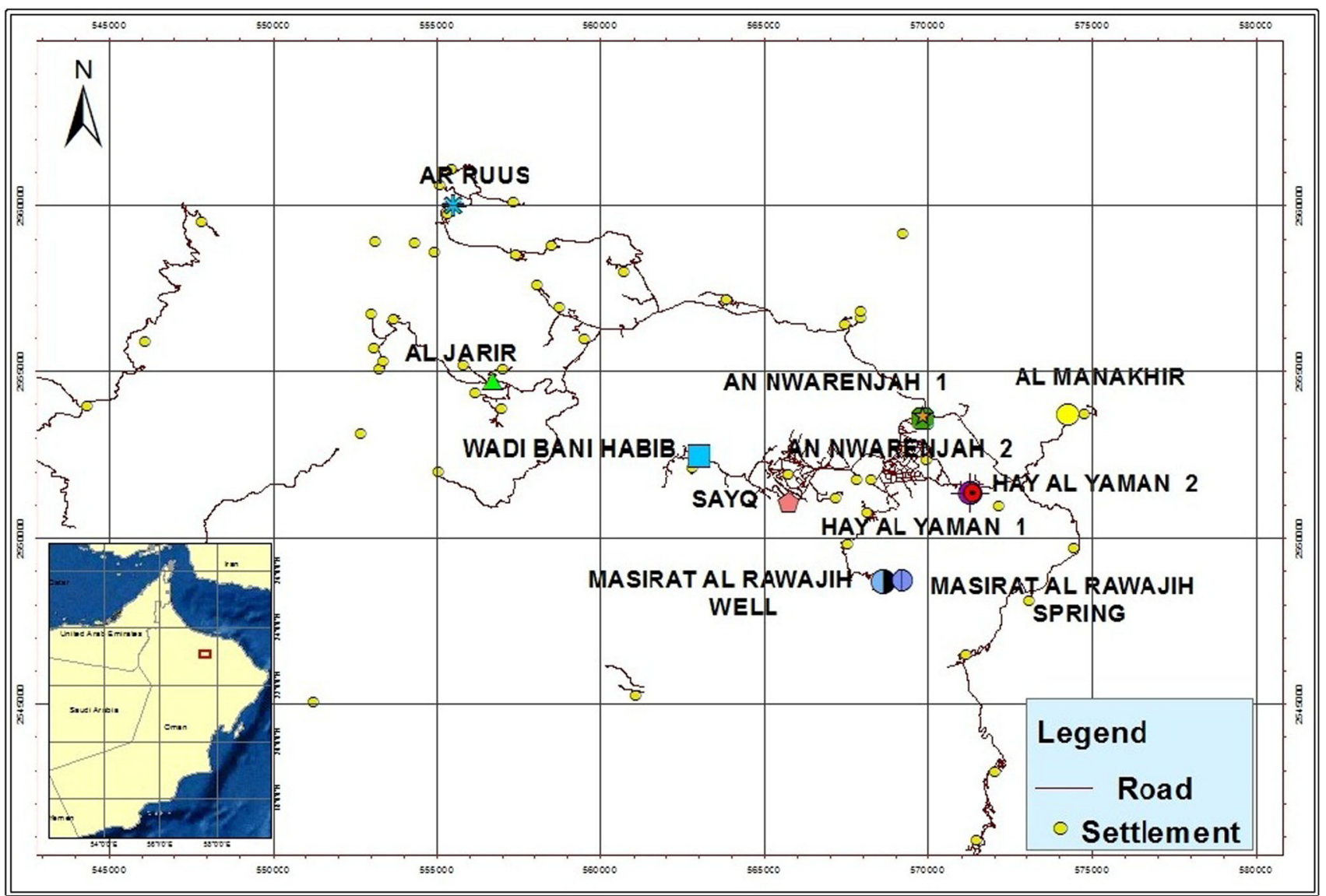

Fig. 1 The locations of sampled groundwater resources of the study area

rocks are highly fractured with karstic topography, allowing groundwater to be stored, migrate over long distances and emerge at the surface via many different springs along the boundary of the formations (Nagieb et al. 2004; Matter et al. 2006). The deeper fractures are likely to be more compressed that the shallow fractures. This implies that the groundwater in the deeper fractures is more confined; movement takes place along the intersection of two joints or a joint and bedding (Mott MacDonald 1992; Mount et al. 1998). The groundwater in the area is found at $<5$ to $30 \mathrm{~m}$ from the surface, and the static water depth ranges between 450 and $2000 \mathrm{~m}$ (Al-Fahdi 2011).

Due to its hydrogeological setting, Al Jabal Al Akhdar is very important as a water catchment area, with three natural freshwater resources: groundwater (wells), aflaj and wadis. Groundwater is the only freshwater available for drinking in the area, accessed via wells established by the Omani government, which supplies the water through networks or water trucks to local communities as well as other governmental offices, armed forces and private businesses. Aflaj (singular falaj) are surface and/or underground channels fed by groundwater, springs, or streams, built to provide water for agriculture (MRMWR 2008).
Aflaj are maintained by designated local people who are responsible for the efficient system of water distribution for irrigation; government agencies are not involved in these indigenous governance structures (Al-Marshudi 2007; MRMWR 2008). Wadis (singular wadi) are seasonal valleys or dry ephemeral riverbeds that contain water only during times of rainfall, and are intercepted by artificial surface storage dams. Water from aflaj and dams is mainly used for agriculture and livestock.

As an arid mountain, water is the lifeline of Jabal Akhdar's ecosystems. Any adverse effects on its water resources will impact all ecosystems including humans; lack of water is a major constraint to local people (AlKalbani 2015). The existing water resources are under threat due to an increase in over-abstraction of water from government wells, the only available water resources for domestic purposes; and excessive use of water from aflaj and dams, the only available resources for agricultural purposes (Al-Kalbani 2015). Water quantity and quality are interconnected, since any changes in water quantity may affect its quality by various ways. The rapid increase in urbanization in the area, together with climatic change (Al- 
Kalbani et al. 2014), is leading to a decrease in water quantity and therefore a deterioration in water quality.

\section{Materials and methods}

\section{Water sampling and analytical methods}

All sources of groundwater were sampled from a valve connected directly to their reservoirs. These include 10 government wells and one natural spring (Fig. 1). The sampling regime was 3 months in winter and 3 months in summer during 2012-2013, taking into account that seasonal events such as rainfall and storms may influence sampling; and to obtain a reasonable range of data in each season. Sample collection, handling and processing followed the methods recommended by the American Public Health Association (APHA 2005); water quality parameters were selected according to Chapman (1996). Major physico-chemical parameters were analyzed in quality assured laboratories in Oman using the analytical methods and instrumental techniques shown in Table 1. The accuracy of the chemical analysis was verified by the calculation of ion-balance errors of $5 \%$ for all the sampled water resources. The respective values for all these parameters are compared with standard limits recommended by Omani standards for Un-bottled Drinking Water 8/2006 (MD 2007) and the World Health Organization (WHO 2011a).

\section{Hydrochemical water quality}

\section{Cation-anion exchange reaction}

Assessment of changes in the chemical composition of water during subsurface movement is essential to understand the dissolution of undesirable constituents in water. Schoeller (1977) suggested chloro-alkaline indices, which indicate ion exchange between groundwater and its host environment during residence or travel. This index is positive if $\mathrm{Na}^{+}$and $\mathrm{K}^{+}$ions in water are exchanged with $\mathrm{Ca}^{2+}$ and $\mathrm{Mg}^{2+}$; indicating a direct base exchange reaction. If the index is negative, the exchange is indirect, indicating chloro-alkaline disequilibrium. The chloro-alkaline indices (CAI-1 and CAI-2) were used for the assessment of cationanion exchange reaction and calculated using the following formula:

$$
\begin{aligned}
\mathrm{CAI}-1= & \mathrm{Cl}^{-}-\left(\mathrm{Na}^{+}+\mathrm{K}^{+}\right) / \mathrm{Cl}^{-}, \\
\mathrm{CAI}-2= & \mathrm{Cl}^{-}-\left(\mathrm{Na}^{+}+\mathrm{K}^{+}\right) / \\
& \left(\mathrm{CO}_{3}^{2-}+\mathrm{HCO}_{3}^{-}+\mathrm{SO}_{4}^{2-}+\mathrm{NO}_{3}^{-}\right),
\end{aligned}
$$

\begin{tabular}{|c|c|}
\hline Parameters & Method/instrument used \\
\hline Electrical conductivity (EC) & $\begin{array}{l}\text { Measured in the field using a battery-operated conductivity meter (SevenGo, Mettler-Toledo } \\
\text { AG } 8603 \text { Schwerzenbach, Switzerland) and in the laboratory using the Orion Thermo 550A }\end{array}$ \\
\hline $\mathrm{pH}$ & $\begin{array}{l}\text { Determined in the field using a } \mathrm{pH} \text { meter (SevenGo, Mettler-Toledo } \mathrm{GmbH}, 8603 \\
\text { Schwerzenbach, Switzerland), and in the laboratory using a } \mathrm{pH} \text { meter (Mettler Toledo) }\end{array}$ \\
\hline Total dissolved solids (TDS) & Gravimetric method \\
\hline Turbidity & Turbidity meter (Orion AQ 4500), nephelometric turbidity units (NTU) \\
\hline Alkalinity $\left(\mathrm{CaCO}_{3}, \mathrm{HCO}_{3}\right.$ and $\left.\mathrm{CO}_{3}\right)$ & Autotitration \\
\hline Total hardness $(\mathrm{TH})\left(\mathrm{mg} \mathrm{l}^{-1}\right)$ & $=2.497\left(\right.$ calcium mg $\left.1^{-1}\right)+4.118\left(\right.$ magnesium mg $\left.1^{-1}\right)($ Todd 2005$)$ \\
\hline Dissolved oxygen (DO) & $\begin{array}{l}\text { Measured in the field using Multi Probe System/data logger, YSI Incorporated } 556 \text { Instrument, } \\
\text { Bramum Lane and in the laboratory using Mettler Toledo Seven Go Pro }\end{array}$ \\
\hline Biochemical oxygen demand $\left(\mathrm{BOD}_{5}\right)$ & $\begin{array}{l}\mathrm{BOD}_{5}=\left(D_{2}-D_{1}\right) / P \text {, where } \\
D_{1} \text { : DO of diluted sample immediately after preparation, } \mathrm{mg}^{-1} \\
D_{2} \text { : DO of diluted sample after } 5 \text { days incubation at } 20{ }^{\circ} \mathrm{C}, \mathrm{mg} \mathrm{l}^{-1} \\
P \text { : Decimal volumetric fraction of sample used }\end{array}$ \\
\hline $\begin{array}{l}\text { Sodium }(\mathrm{Na}) \text {, calcium }(\mathrm{Ca}) \text {, magnesium }(\mathrm{Mg}) \text {, } \\
\text { potassium }(\mathrm{K})\end{array}$ & Inductively Coupled Plasma (ICP-OES) method (Perkin-Elmer Optima 3300 DV) \\
\hline $\begin{array}{l}\text { Fluoride }(\mathrm{F}) \text {, chloride }(\mathrm{Cl}) \text {, nitrate }\left(\mathrm{NO}_{3}\right) \text {, sulfate } \\
\quad\left(\mathrm{SO}_{4}\right) \text {, phosphate }\left(\mathrm{PO}_{4}\right)\end{array}$ & $\begin{array}{l}\text { Metrohm Professional Compact Ion Chromatography System } 881 \text { with Metrohm } 858 \\
\text { Professional Sample Processor }\end{array}$ \\
\hline Heavy metals & Inductively Coupled Plasma (Perkin-Elmer Optima 3300 DV) \\
\hline Coliform bacteria & IDEXX Quanti-Tray (51-Well Quanti-Tray) quantification methods (most probable number) \\
\hline Escherichia coli & Spectroline Model (EA-160/FE), ultraviolet light (365 nm) \\
\hline
\end{tabular}

where the concentrations are expressed in meq $1^{-1}$.

Table 1 Determination of physico-chemical water quality parameters by different methods/instruments 


\section{Groundwater-aquifers relationship}

The chemical components of drinking water and its relationship with their aquifers play a significant role in water quality. Gibbs (1970) has recommended diagrams in which ratio of dominant anions and cations are plotted against total dissolved solids (TDS). These diagrams are widely used to assess the functional sources of dissolved chemical constituents in relation to aquifers, such as chemistry of rock types, precipitated water, and rate of evaporation. The ratio 1 , for cations, and ratio 2, for anions, in the sampled drinking water resources were calculated using the following equations.

Gibbs ratio 1 for cations $=\left(\mathrm{Na}^{+}+\mathrm{K}^{+}\right) /$

$$
\left(\mathrm{Na}^{+}+\mathrm{K}^{+}+\mathrm{Ca}^{2+}\right)
$$

Gibbs ratio 2 for anions $=\mathrm{Cl}^{-} /\left(\mathrm{Cl}^{-}+\mathrm{HCO}_{3}^{-}\right)$.

\section{Piper's trilinear diagram}

Major cations and anions such as $\mathrm{Na}^{+}, \mathrm{Ca}^{2+}, \mathrm{Mg}^{2+}, \mathrm{K}^{+}$, $\mathrm{Cl}^{-}, \mathrm{CO}_{3}{ }^{2-}, \mathrm{HCO}_{3}{ }^{-}$and $\mathrm{SO}_{4}{ }^{2-}$ were plotted in Piper's trilinear diagram (Piper 1944) to assess the hydrochemistry of drinking water resources (Fig. 2). The concept of hydrochemical facies using this diagram was developed to understand and identify the water composition in different classes (Sadashivaiah et al. 2008). These trilinear diagrams are useful in bringing out chemical relationships among groundwater samples in more definite terms rather than with other possible plotting methods (Sajil Kumar 2013). To assess the hydrochemistry of groundwater resources of the study area, Piper's trilinear diagram was plotted using GW Chart (USGS 2014).

\section{Water quality index}

A water quality index (WQI) is an important parameter for demarcating groundwater quality and a rating technique for its suitability for drinking purposes (Nasirian 2007; Varol and Davraz 2015). It has been considered as one criterion for drinking water classification, based on the use of standard parameters for water characterization (Giriyappanavar and Patil 2013). A commonly used WQI was developed by the National Sanitation Foundation (NSF) in 1970 (Tyagi et al. 2013). Therefore, NSF-WQI is a standardized method for communicating and comparing the quality of various water bodies and simplifying the report of water characterization data into a single number, representing the water quality level (González et al. 2012; Arumugam et al. 2014). The index summarizes results from nine different measurements: temperature, $\mathrm{pH}$, dissolved oxygen, turbidity, fecal coliform, biochemical oxygen demand, total phosphates, nitrates, and total suspended solids (Karbassi et al. 2011; Kushwaha and Kumar 2014). The water quality data are recorded and transferred to a weighting curve chart; the relative weights (Table 2) are preserved for each factor and scaled to obtain a numerical value of $Q_{i}$, so that the range remains from 0 (very bad water quality) to 100 (excellent water quality). The mathematical expression for the NSF-WQI is given by:

$$
\mathrm{WQI}=\sum\left(Q_{i} W_{i}\right) \text {, }
$$

Fig. 2 Piper-trilinear diagram presenting anion and cation facies in the form of major ion percentages. Groundwater types are classified according to the domain in which they occur on the diagram segments (after Sadashivaiah et al. 2008)

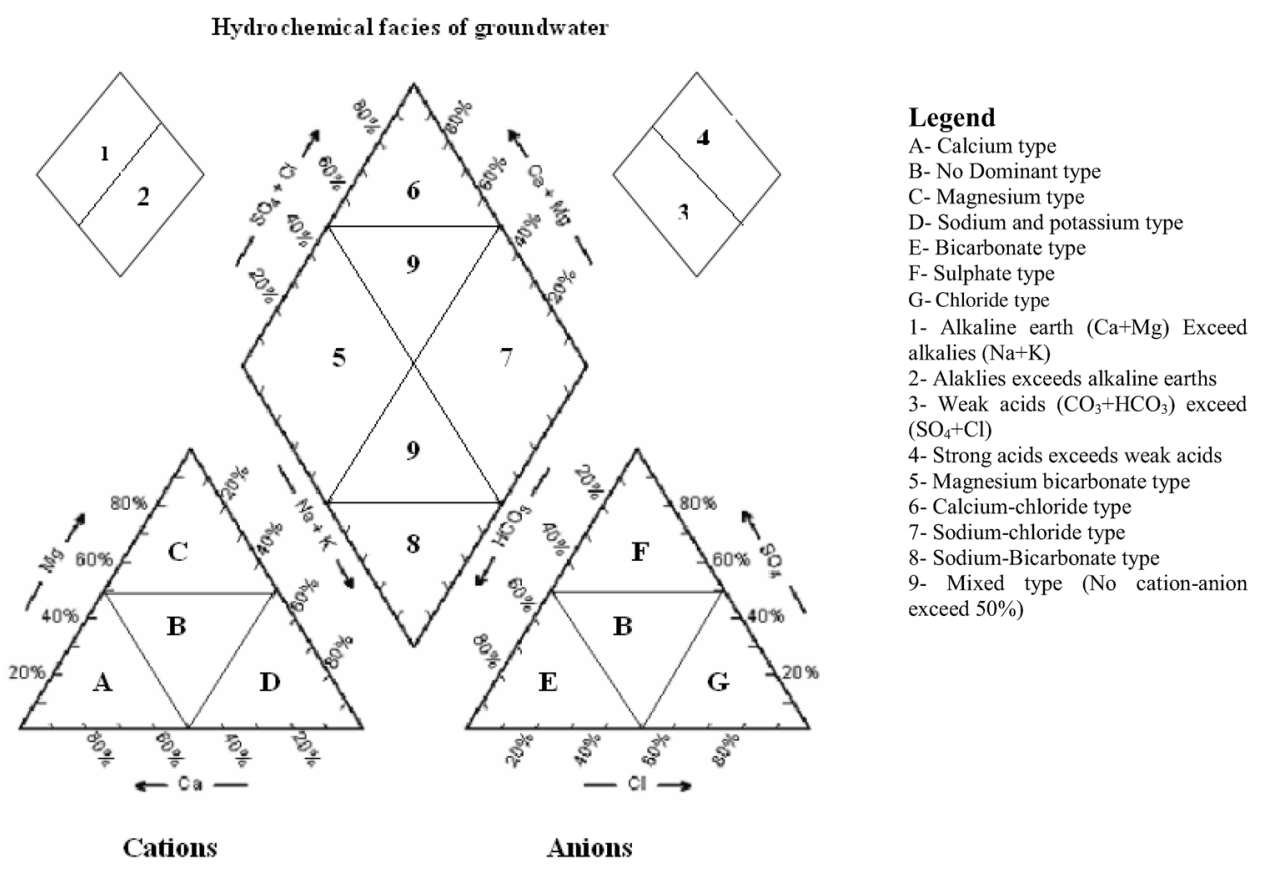

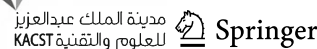


Table 2 Water quality parameters and weights based on NSF-WQI (after WU 2014)

\begin{tabular}{lll}
\hline Parameter & Units & Weight \\
\hline Dissolved oxygen & \% saturation & 0.17 \\
Fecal coliform & MPN $100 \mathrm{ml}^{-1}$ & 0.16 \\
$\mathrm{pH}$ & & 0.11 \\
Biochemical oxygen demand & $\mathrm{mg} \mathrm{l}^{-1}$ & 0.11 \\
Temperature change & ${ }^{\circ} \mathrm{C}$ & 0.10 \\
Total phosphate & $\mathrm{mg} \mathrm{l}^{-1}$ & 0.10 \\
Nitrates & $\mathrm{mg} \mathrm{l}^{-1}$ & 0.10 \\
Turbidity & $\mathrm{NTU}^{-1}$ & 0.08 \\
Total dissolved solids & $\mathrm{mg} \mathrm{l}^{-1}$ & 0.07 \\
\hline
\end{tabular}

Table 3 Classification criteria standards based on NSF-WQI (after Tyagi et al. 2013)

\begin{tabular}{llll}
\hline Range & Descriptive status & Category & Remarks \\
\hline $91-100$ & Excellent & A & Non polluted \\
$71-90$ & Good & B & Non polluted \\
$51-70$ & Medium & C & Polluted \\
$26-50$ & Bad & D & Heavily polluted \\
$0-25$ & Very bad & E & Heavily polluted \\
\hline
\end{tabular}

where $Q_{i}$ is the sub-index for $i$ th water quality parameter; $W_{i}$ is the weight associated with $i$ th (1 to $\left.n\right)$ water quality parameter; $n$ is the number of water quality parameters.
The index can be divided into several ranges corresponding to the general ratings of descriptive terms and categories of water quality as shown in Table 3. To calculate the WQI for sampled water resources of the study area, the weighted averages of each parameter were calculated, and the sub-index of each parameter was determined, and WQI was finally calculated using the software available at Wilkes University (WU 2014) website.

\section{Results and discussion}

\section{Physico-chemical parameters of groundwater resources}

The means, medians, standard deviations, minima and maxima of drinking water quality parameters are presented in Table 4. Electrical conductivity (EC) values ranged from 425 to $1295 \mu \mathrm{s} \mathrm{cm}^{-1}$ (mean $748 \mu \mathrm{s} \mathrm{cm}^{-1}$ ) in summer, and from 437 to $1507 \mu \mathrm{s} \mathrm{cm}^{-1}$ (mean $825 \mu \mathrm{s} \mathrm{cm}^{-1}$ ) in winter. None of the samples exceed the limits of the recommended Omani standards for Un-bottled Drinking Water (MD 2007) and World Health Organization standard (WHO 2011a). During summer, the $\mathrm{pH}$ value ranged from 8.1 to 8.5 ; during winter, from 7.3 to 8.2. Thus, the water is slightly alkaline. These $\mathrm{pH}$ values are within the limits of the recommended Omani and WHO standards (6.5-9.5). TDS values ranged from 238 to $920 \mathrm{mg} \mathrm{l}^{-1}$ (mean $449 \mathrm{mg} \mathrm{l}^{-1}$ ) in summer, and during winter from 317 to $980 \mathrm{mg} \mathrm{l}^{-1}$ (mean $535 \mathrm{mg}^{-1}$ ). These were within the

Table 4 Mean, median, standard deviation, minimum and maximum of groundwater quality variables of the study area in 2012-2013

\begin{tabular}{|c|c|c|c|c|c|c|c|}
\hline Variables & Mean & Median & Std. deviation & Minimum & Maximum & Omani standard & WHO standard \\
\hline $\mathrm{EC}\left(\mu \mathrm{S} \mathrm{cm}{ }^{-1}\right)$ & 786.42 & 649.95 & 284.04 & 431.20 & 1401.00 & $160-1600$ & 2000 \\
\hline $\mathrm{pH}$ & - & 7.98 & 0.24 & 7.68 & 8.35 & $6.5-9.0$ & $6.5-9.5$ \\
\hline $\operatorname{TDS}\left(m g 1^{-1}\right)$ & 492.22 & 398.12 & 198.19 & 277.44 & 949.66 & $120-1000$ & 1000 \\
\hline Turbidity (NTU) & 3.27 & 0.19 & 7.38 & 0.05 & 20.45 & 1 to $<5$ & NG \\
\hline Alkalinity $\left(\mathrm{CaCO}_{3}\right)\left(\mathrm{mg}^{-1}\right)$ & 273.36 & 261.53 & 66.92 & 176.38 & 379.60 & NG & NG \\
\hline Alkalinity $\left(\mathrm{HCO}_{3}\right)\left(\mathrm{mg} \mathrm{l}^{-1}\right)$ & 297.21 & 284.85 & 71.92 & 189.79 & 410.95 & NG & NG \\
\hline Total hardness $\left(\mathrm{mg} \mathrm{l}^{-1}\right)$ & 346.94 & 327.55 & 112.22 & 206.75 & 566.73 & $\leq 200$ to 500 & 500 \\
\hline Sodium (Na) $\left(\mathrm{mg} \mathrm{l}^{-1}\right)$ & 36.77 & 26.19 & 28.98 & 12.51 & 97.77 & $\leq 200$ to 400 & 200 \\
\hline Calcium (Ca) $\left(\mathrm{mg} \mathrm{l}^{-1}\right)$ & 77.08 & 66.76 & 34.19 & 35.32 & 145.60 & 200 & NG \\
\hline Magnesium (Mg) $\left(\mathrm{mg} \mathrm{l}^{-1}\right)$ & 31.85 & 30.06 & 7.81 & 22.14 & 44.42 & 150 & NG \\
\hline Potassium $(\mathrm{K})\left(\mathrm{mg} \mathrm{l}^{-1}\right)$ & 2.98 & 1.70 & 2.81 & 0.56 & 8.21 & NG & NG \\
\hline Fluoride $(\mathrm{F})\left(\mathrm{mg} \mathrm{l}^{-1}\right)$ & 0.26 & 0.24 & 0.14 & 0.11 & 0.46 & 1.5 & 1.5 \\
\hline Chloride $(\mathrm{Cl})\left(\mathrm{mg} \mathrm{l}^{-1}\right)$ & 51.91 & 28.99 & 46.58 & 17.44 & 165.14 & $\leq 250$ to 600 & 250 \\
\hline Nitrate $\left(\mathrm{NO}_{3}\right)\left(\mathrm{mg} \mathrm{l}^{-1}\right)$ & 18.49 & 9.36 & 23.49 & 0.73 & 72.77 & 50 & 50 \\
\hline Sulfate $\left(\mathrm{SO}_{4}\right)\left(\mathrm{mg} \mathrm{l}^{-1}\right)$ & 56.64 & 42.04 & 35.57 & 19.06 & 114.10 & $\leq 250$ to 400 & 400 \\
\hline Phosphate $\left(\mathrm{PO}_{4}\right)\left(\mathrm{mg} \mathrm{l}^{-1}\right)$ & 0.16 & 0.06 & 0.27 & 0.02 & 0.93 & NG & NG \\
\hline Coliforms (MPN $100 \mathrm{ml}^{-1}$ ) & 6.65 & 0.00 & 18.22 & 0.00 & 61.30 & 10 & 10 \\
\hline
\end{tabular}

$N G$ no guideline is recommended 
Table 5 The chloro-alkaline indices (CAI-1 and CAI-2) for groundwater resources of the study area sampled during summer and winter 2012-2013

\begin{tabular}{lrrrrr}
\hline Sample code & \multicolumn{2}{l}{ Summer } & & \multicolumn{2}{l}{ Winter } \\
\cline { 2 - 3 } \cline { 5 - 6 } & CAI-1 & CAI-2 & & CAI-1 & \multicolumn{1}{c}{ CAI-2 } \\
\hline G1 & -0.414 & 0.607 & & -6.788 & -6.216 \\
G2 & -0.258 & 0.624 & & -9.300 & -8.167 \\
G3 & -0.196 & 0.590 & & -17.026 & -10.427 \\
G4 & -0.263 & 0.560 & & -14.603 & -10.947 \\
G5 & 1.083 & 1.674 & & -0.286 & 0.114 \\
G6 & 0.682 & 1.837 & & -2.108 & 0.278 \\
G7 & -0.318 & 0.735 & & -12.239 & -5.481 \\
G8 & -0.307 & 0.686 & & -4.859 & -4.454 \\
G9 & -0.027 & 0.437 & & -5.850 & -7.850 \\
G10 & 1.160 & 2.658 & -2.493 & 0.417 \\
\hline
\end{tabular}

permissible levels of TDS (120-600 $\mathrm{mg}^{-1}$, maximum $1200 \mathrm{mg} \mathrm{l}^{-1}$ ) in the Omani standard; the WHO standard allows for a maximum level of $1000 \mathrm{mg}^{-1}$. Hardness of groundwater results from the presence of divalent metallic cations of which concentration of $\mathrm{Ca}^{2+}$ and $\mathrm{Mg}^{2+}$ are most abundant in groundwater. Both Omani and WHO standards allow a maximum of $500 \mathrm{mg} \mathrm{l}^{-1}$ for total water hardness. Of the 11 groundwater samples analyzed, only one well located at Sayq village had a total hardness of $516 \mathrm{mg} \mathrm{l}^{-1}$ in summer and $617 \mathrm{mg} \mathrm{l}^{-1}$ in winter. The mean total hardness of all drinking water resources was 333 and $361 \mathrm{mg} \mathrm{l}^{-1}$ during summer and winter, respectively. Adopting Sawyer $(1994,2003)$ classification criteria, groundwater of the entire study area is hard to very hard as the total hardness $\left(\mathrm{CaCO}_{3}\right)$ is in the range of $150-300$ and more than $300 \mathrm{mg}^{-1}$. The hardness of the water is due to the presence of alkaline earths such as calcium and magnesium, and anions such as carbonate, bicarbonate, chloride and sulfate.

Concentrations of all cations and anions in the samples were not significantly different between summer and winter; except fluoride. The mean concentration of cations (in $\mathrm{mg} \mathrm{l^{-1 }}$ ) in the samples was: $\mathrm{Ca}^{2+}>\mathrm{Na}^{+}>\mathrm{Mg}^{2+}>\mathrm{K}^{+}$ (Table 5). The mean concentration of anions (in $\mathrm{mg}^{-1}$ ) was: $\quad \mathrm{HCO}_{3}{ }^{-}>\mathrm{SO}_{4}{ }^{2-}>\mathrm{Cl}^{-}>\mathrm{NO}_{3}{ }^{-}>\mathrm{CO}_{3}{ }^{2-}>-$ $\mathrm{F}^{-}>\mathrm{PO}_{4}{ }^{2-}$. According to Omani and WHO standards, all cations and anions concentrations in all samples were within the permissible limits. However, nitrate concentrations in some groundwater wells were higher than the desirable limit of $50 \mathrm{mg} \mathrm{l}^{-1}$ for drinking water (Fig. 3). For example, Hayl Al Yaman well (2) showed a high concentration of nitrate of $101.45 \mathrm{mg} \mathrm{l}^{-1}$ in the winter sample, and a high concentration of $42.75 \mathrm{mg} \mathrm{l}^{-1}$, not exceeding the limit, in the summer sample. Nearby Hayl Al Yaman well (1) showed a nitrate concentration of $44.10 \mathrm{mg} \mathrm{l}^{-1}$ in the summer sample. Other samples did not exceed the standards limit, but increased from summer to winter: Al Manakhir well (31.05-38.68 $\mathrm{mg} \mathrm{l}^{-1}$ ); Sayq well (22.78-40.22 $\mathrm{mg} \mathrm{l}^{-1}$ ). The possible sources of high nitrate in these wells are from the seepage of sewage water from unlined septic tanks in some of the households near these wells. Most of the households in the study area are not connected to a sewer system. Nitrate as such is not poisonous but when reduced to nitrite in the stomach it can be toxic, particularly to bottle-fed babies (blue baby syndrome or methemoglobinemia (WHO 2011b). High nitrate concentration in drinking water can also create problems including cyanosis, goiter, oral cancer, cancer of the colon or rectum, other gastrointestinal cancers, lymphoma and dyspnea (Tatawat and Chandel 2008).

Although the amount of dissolved oxygen (DO) often gives a good indication of water quality, Omani and WHO
Fig. 3 Nitrate concentration in groundwater resources of the study area sampled during summer and winter 2012-2013

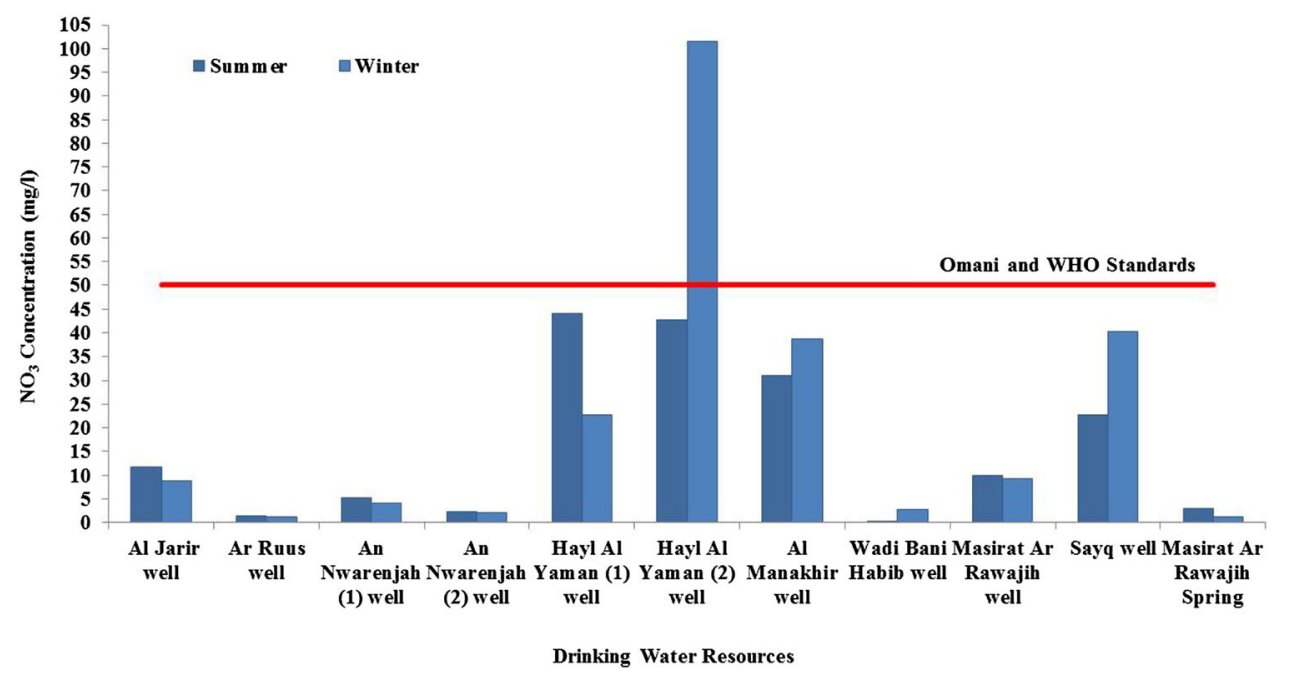

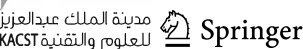


Table 6 Ratio 1 for cations and ratio 2 for anions of groundwater resources of the study area sampled during summer and winter 2012-2013

\begin{tabular}{|c|c|c|c|c|}
\hline \multirow{2}{*}{$\begin{array}{l}\text { Sample } \\
\text { code }\end{array}$} & \multicolumn{2}{|l|}{ Summer } & \multicolumn{2}{|l|}{ Winter } \\
\hline & $\begin{array}{l}\text { Ratio } 1 \\
\text { cations }\end{array}$ & $\begin{array}{l}\text { Ratio } 2 \\
\text { anions }\end{array}$ & $\begin{array}{l}\text { Ratio } 1 \\
\text { cations }\end{array}$ & $\begin{array}{l}\text { Ratio 2 } \\
\text { anions }\end{array}$ \\
\hline G1 & 0.216 & 0.192 & 0.256 & 0.175 \\
\hline G2 & 0.222 & 0.171 & 0.491 & 0.137 \\
\hline G3 & 0.142 & 0.127 & 0.495 & 0.097 \\
\hline G4 & 0.142 & 0.122 & 0.166 & 0.123 \\
\hline G5 & 0.284 & 0.364 & 0.609 & 0.404 \\
\hline G6 & 0.574 & 0.397 & 0.262 & 0.433 \\
\hline G7 & 0.166 & 0.122 & 0.187 & 0.158 \\
\hline G8 & 0.158 & 0.144 & 0.248 & 0.228 \\
\hline G9 & 0.245 & 0.149 & 0.444 & 0.121 \\
\hline G10 & 0.594 & 0.385 & 0.358 & 0.472 \\
\hline G11 & 0.214 & 0.149 & 0.236 & 0.169 \\
\hline
\end{tabular}

standards do not recommend guidelines regarding the acceptability of low levels. Generally, concentrations in unpolluted waters are usually close to, but less than $10 \mathrm{mg}^{-1}$; concentrations below $5 \mathrm{mg}^{-1}$ may adversely affect the functioning and survival of biological communities (Chapman and Kimstach 1996). All samples had DO concentrations close to, but less than, $10 \mathrm{mg} \mathrm{l}^{-1}$, taking into account changes in field water temperatures. The mean field measurements of DO in samples ranged from 6.86 to $8.35 \mathrm{mg} \mathrm{l}^{-1}$ (mean $7.85 \mathrm{mg} \mathrm{l}^{-1}$ ) in summer and from 7.30 to $8.97 \mathrm{mg}^{-1}$ (mean $7.99 \mathrm{mg} \mathrm{l}^{-1}$ ) in winter. Omani and WHO standards also do not set guideline values for biochemical oxygen demand $\left(\mathrm{BOD}_{5}\right)$. However, unpolluted waters typically have $\mathrm{BOD}_{5}$ values of $2 \mathrm{mg} \mathrm{l}^{-1}$ or less whereas those receiving wastewater may have values up to
$10 \mathrm{mg} \mathrm{l}^{-1}$ or more (Chapman and Kimstach 1996). The mean $\mathrm{BOD}_{5}$ for all samples was $1.26 \mathrm{mg} \mathrm{l}^{-1}$; values ranged from 0.36 to $1.74 \mathrm{mg} \mathrm{l}^{-1}$ during summer and ranged from 0.08 to $1.24 \mathrm{mg} \mathrm{l}^{-1}$ (mean $0.57 \mathrm{mg} \mathrm{l}^{-1}$ ) during winter. The Omani and WHO standards for coliform bacteria allow the most probable number (MPN) of 10 per $100 \mathrm{ml}$. In both guidelines, total E. coli should be 0 per $100 \mathrm{ml}$ of a sample. Of the 11 summer samples, only 3 showed the presence of total coliform bacteria; during winter, only one sample was positive. No sample showed any presence of $E$. coli, indicating that this water is safe to use and drink.

\section{Hydrochemical quality of groundwater resources}

Around $91 \%$ of the samples had negative chloro-alkaline indices (CAI-1 and CAI-2), indicating indirect exchange and therefore chloro-alkaline disequilibrium (Table 5). These results show that there is ion exchange between the water and its host environment during its travel in the subsurface, with the dissolution of undesirable constituents in water.

The results of ratio 1 (cations) and ratio 2 (anions) in the samples are presented in Table 6. The Gibbs diagrams (Fig. 4) showed that the majority of the samples are in the rock-water interaction dominance field, suggesting that chemical weathering of rocks forming minerals and evaporation are the dominant processes controlling the major ion composition of the water through the dissolution of the rock-forming minerals. Similar results were found by other studies conducted in arid regions (e.g., Magesh et al. 2013; Al-Harbi et al. 2014; Huang et al. 2014; Nazzal et al. 2014; Aly 2014; Saber et al. 2014).
Fig. 4 Gibbs diagrams for hydro-chemical quality of groundwater resources of the study area (after Gibbs 1970)
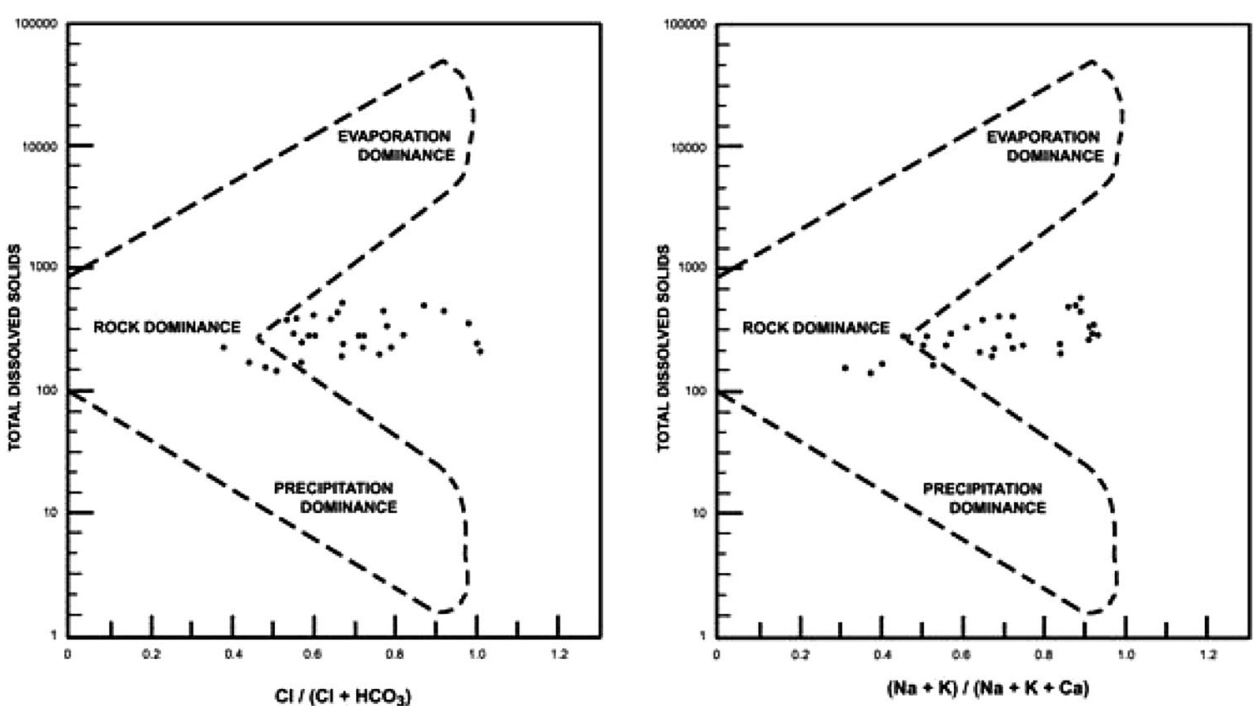


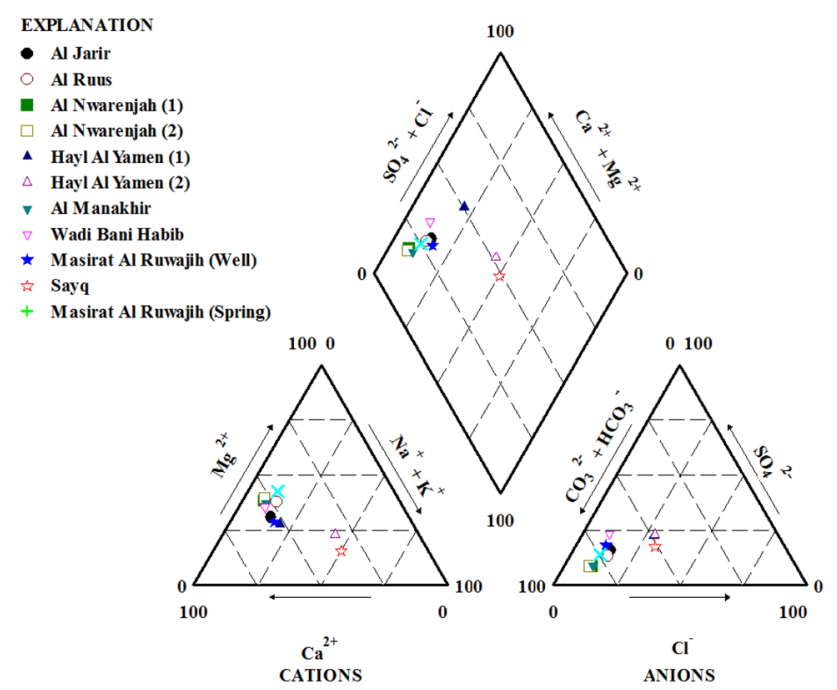

Fig. 5 Piper's trilinear diagram of groundwater resources of the study area sampled during summer 2012-2013

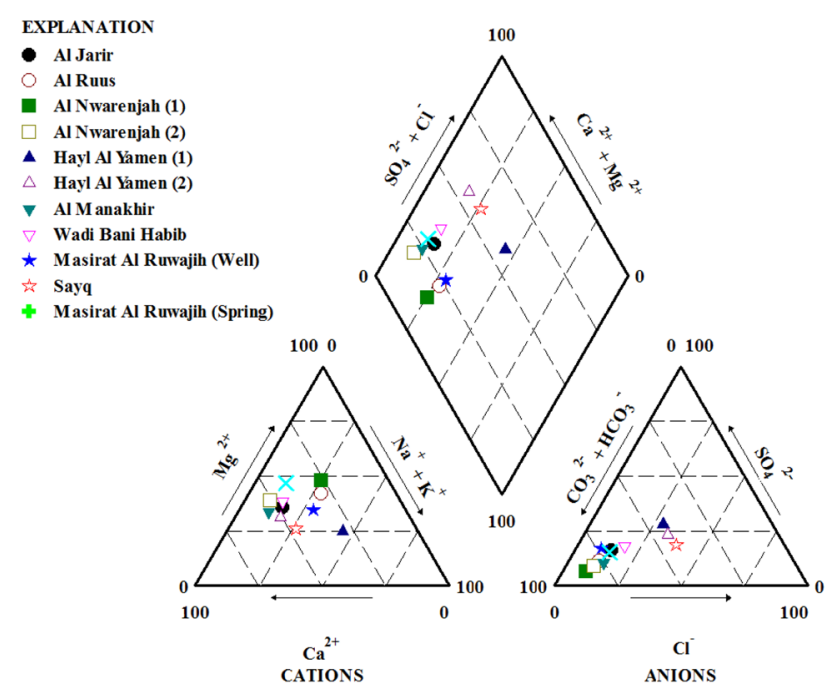

Fig. 6 Piper's trilinear diagram of groundwater resources of the study area sampled during winter 2012-2013

\section{Hydrochemical facies of groundwater resources}

Figures 5 and 6 present the chemical data analysis, using Piper's trilinear diagram, of all the samples. These diagrams reveal the analogies, dissimilarities and different types of waters in the study area, which are identified based on domain categories in which they occur on the diagram segments (Table 7). Most of the summer and winter samples fall in the field (A) of calcium and (E) bicarbonate types, representing 27 and $73 \%$ of the water samples, respectively.

The characteristics of corresponding subdivisions of diamond-shaped fields show all samples are of field 1 (100\%), followed by fields 3 and 5 (each $73 \%$ ), then fields 4 and 9 (each 27\%). These results suggest that most of the groundwater is of calcium and bicarbonate types; alkaline earth $(\mathrm{Ca}+\mathrm{Mg})$ dominates over alkalis $(\mathrm{Na}+\mathrm{K})$, and weak acids $\left(\mathrm{CO}_{3}+\mathrm{HCO}_{3}\right)$ over strong acids $\left(\mathrm{SO}_{4}+\mathrm{Cl}\right)$. These results suggest that the water chemistry is originated mainly from dissolution of carbonate rocks with low salinity. This is in agreement with Matter et al. (2006) who found that groundwater in the recharge areas of $\mathrm{Al} \mathrm{Jabal} \mathrm{Al}$ Akhdar is of $\mathrm{Ca}-\mathrm{Mg}-\mathrm{HCO}_{3}$ type water. This type is typical for the Hajar Supergroup aquifer for limestone and dolomite dominated environments. There is no significant change in the hydro-chemical facies between summer and winter, indicating that most of the major ions are natural in origin, due to groundwater passing through relatively insoluble igneous rocks and dissolving only small quantities of minerals. These results are in line with other studies carried out in arid environment (e.g., Ayuba et al. 2013; Aly et al. 2014; Al-Khashman and Jaradat 2014; Alaya et al. 2014; Varol and Davraz 2015).

\section{Correlation of groundwater quality indicators}

Correlations analysis using Pearson's coefficient $(r)$ of physicochemical parameters of groundwater quality are presented in Table 8 . The terms strongly, moderately and weakly correlations refer to $r>0.7, r=0.5-0.7$, and $r<0.5$, respectively. The correlation coefficient matrix for these parameters showed strongly positive correlations, highly significant at $p<0.01$, between TDS, turbidity, EC, $\mathrm{TH}, \mathrm{Na}^{+}, \mathrm{Ca}^{2+}, \mathrm{Mg}^{2+}, \mathrm{Cl}^{-}, \mathrm{NO}_{3}{ }^{-}$, and $\mathrm{SO}_{4}{ }^{2-}$. The strongest positive correlation was between EC and TDS $(r=0.986)$ : highly statistically significant at $p<0.01$. High correlation was also found among TDS with $\mathrm{Na}^{+}$, $\mathrm{Ca}^{2+}, \mathrm{Mg}^{2+}$ and $\mathrm{Cl}^{-}$. Other statistically significant positive correlations $(p<0.01)$ were found between $\mathrm{HCO}_{3}{ }^{-}$, EC, $\mathrm{TH}, \mathrm{Ca}^{2+}$ and $\mathrm{Mg}^{2+}$, and between $\mathrm{pH}$ and $\mathrm{CO}_{3}{ }^{2-}$. Strong positive correlation was found between $\mathrm{Ca}^{2+}$ with $\mathrm{Mg}^{2+}$, $\mathrm{Cl}^{-}, \mathrm{NO}_{3}{ }^{-}$and $\mathrm{SO}_{4}{ }^{2-}$. Magnesium was strongly positive and significantly correlated with $\mathrm{Cl}^{-}$and $\mathrm{NO}_{3}$, while sodium was positively and strongly correlated with $\mathrm{Cl}^{-}$and $\mathrm{SO}_{4}{ }^{2-}$. These observations clearly identify the main elements contributing to the groundwater salinity and mineralization. The strongest and highly significant correlation $(r=0.789)$ between $\mathrm{Ca}^{2+}$ and $\mathrm{Mg}^{2+}$ indicates the presence of a ubiquitous source of alkaline earths in groundwater. The high moderately significant relationship $(r=0.602)$ between $\mathrm{Mg}^{2+}$ and $\mathrm{Cl}^{-}$, and strongly significant relationship between total hardness with $\mathrm{Ca}^{2+}$ $(r=0.898)$ and $\mathrm{Mg}^{2+}(r=0.925)$, indicated that the hardness of the water was permanent in nature. The highly significant and strong correlation $(r=0.851)$ between $\mathrm{Cl}^{-}$ and $\mathrm{Na}^{+}$confirms their same origin, that is, the dissolution of the halite resulting from the action of water on salts. The concentrations of $\mathrm{SO}_{4}{ }^{2-}$ are tightly correlated with the 
Table 7 Characterization of groundwater resources of the study area sampled during 2012-2013 according to the Piper trilinear diagram

\begin{tabular}{llr}
\hline Subdivision of the diamond & Characteristics of corresponding subdivisions of diamond-shaped fields & \% of samples in this category \\
\hline 1 & Alkaline earth $(\mathrm{Ca}+\mathrm{Mg})$ Exceed alkalies $(\mathrm{Na}+\mathrm{K})$ & 100 \\
2 & Alaklies exceeds alkaline earths & 73 \\
3 & Weak acids $\left(\mathrm{CO}_{3}+\mathrm{HCO}_{3}\right)$ exceed $\left(\mathrm{SO}_{4}+\mathrm{Cl}\right)$ & 27 \\
4 & Strong acids exceeds weak acids & 73 \\
5 & Magnesium bicarbonate type & 0 \\
6 & Calcium-chloride type & 0 \\
7 & Sodium-chloride type & 0 \\
8 & Sodium-bicarbonate type & 27 \\
9 & Mixed type (no cation-anion exceed 50\%) & 27 \\
A & Calcium type & 73 \\
$\mathrm{E}$ & Bicarbonate type & 73 \\
\hline
\end{tabular}

Table 8 Correlation matrix among different water quality parameters for groundwater resources of the study area sampled during 2012-2013

\begin{tabular}{|c|c|c|c|c|c|c|c|c|c|c|c|c|c|c|c|}
\hline & TR & TDS & $\mathrm{EC}$ & $\mathrm{pH}$ & $\mathrm{HCO}_{3}$ & $\mathrm{CO}_{3}$ & $\mathrm{TH}$ & $\mathrm{Na}$ & $\mathrm{Ca}$ & $\mathrm{Mg}$ & $\mathrm{K}$ & $\mathrm{F}$ & $\mathrm{Cl}$ & $\mathrm{NO}_{3}$ & $\mathrm{SO}_{4}$ \\
\hline \multicolumn{16}{|l|}{ TR } \\
\hline TDS & $0.60 * *$ & & & & & & & & & & & & & & \\
\hline $\mathrm{EC}$ & $0.58 * *$ & $0.99 * *$ & & & & & & & & & & & & & \\
\hline $\mathrm{pH}$ & -0.37 & -0.35 & -0.30 & & & & & & & & & & & & \\
\hline $\mathrm{HCO}_{3}$ & 0.34 & $0.53^{*}$ & $0.56^{* *}$ & -0.11 & & & & & & & & & & & \\
\hline $\mathrm{CO}_{3}$ & -0.24 & -0.29 & -0.23 & $0.67 * *$ & 0.07 & & & & & & & & & & \\
\hline $\mathrm{TH}$ & $0.61^{\prime \prime}$ & $0.85^{* *}$ & $0.87 * *$ & $-0.44 *$ & $0.75^{* *}$ & -0.24 & & & & & & & & & \\
\hline $\mathrm{Na}$ & 0.40 & $0.78 * *$ & $0.78 * *$ & -0.03 & 0.21 & -0.08 & 0.39 & & & & & & & & \\
\hline $\mathrm{Ca}$ & $0.49 *$ & $0.80 * *$ & $0.84 * *$ & -0.11 & $0.77 * *$ & -0.06 & $0.90 * *$ & $0.43^{*}$ & & & & & & & \\
\hline $\mathrm{Mg}$ & $0.57 * *$ & $0.74 * *$ & $0.76^{* *}$ & -0.41 & $0.65^{\prime \prime}$ & -0.17 & $0.93 * *$ & 0.26 & $0.79 * *$ & & & & & & \\
\hline K & -0.20 & -0.14 & -0.16 & -0.37 & -0.18 & -0.31 & -0.12 & -0.06 & -0.41 & -0.20 & & & & & \\
\hline F & -0.03 & 0.002 & 0.01 & 0.38 & 0.37 & 0.16 & 0.08 & -0.03 & 0.27 & 0.03 & -0.26 & & & & \\
\hline $\mathrm{Cl}$ & $0.59^{\prime \prime}$ & $0.94 * *$ & $0.94 * *$ & -0.18 & 0.36 & -0.20 & $0.72 * *$ & $0.85 * *$ & $0.74 * *$ & $0.60 * *$ & -0.23 & -0.01 & & & \\
\hline $\mathrm{NO}_{3}$ & 0.04 & $0.66^{* *}$ & $0.71 * *$ & -0.11 & 0.17 & -0.18 & $0.55^{* *}$ & $0.51 *$ & $0.59 * *$ & $0.54 * *$ & -0.08 & -0.13 & $0.66 * *$ & & \\
\hline $\mathrm{SO}_{4}$ & $0.46^{*}$ & $0.82 * *$ & $0.84 * *$ & 0.01 & 0.20 & -0.03 & $0.55^{* *}$ & $0.82 * *$ & $0.62 * *$ & $0.48 *$ & -0.28 & -0.05 & $0.87 * *$ & $0.63 * *$ & \\
\hline
\end{tabular}

*Significantly correlated at 0.05 level

**Significantly correlated at 0.01 level

presence of $\mathrm{Na}^{+}, \mathrm{Ca}^{2+}$ and $\mathrm{Mg}^{2+}$, which is explained by the dissolution of evaporate minerals. These results also reveal that the concurrent increase/decrease in the cations is mainly the result of dissolution/precipitation reactions and concentration effects (Varol and Davraz 2015).

\section{Water quality index}

The WQIs of the sampled groundwater resources were not significantly different between summer and winter $(F=3.092, p=0.094>0.05)$. All water samples are good or medium in quality: B or C categories. The WQI of water samples ranged from 64 to 80 (mean 71.64, median 70 , standard deviation 5.66) during summer. In winter, it ranged from 68 to 83 (mean 75.82, median 76, standard deviation 5.49). Of the 11 summer samples, 5 were classified as good quality and 6 as medium. In winter, 8 were classified as good quality and only 3 as medium (Table 9). WQI showed highly significant and moderately negative correlation with TDS, EC, $\mathrm{Na}^{+}, \mathrm{Ca}^{2+}, \mathrm{Cl}^{-}, \mathrm{NO}_{3}^{-}$and $\mathrm{SO}_{4}{ }^{2-}$ (Table 8), explaining the low WQI value and indicating that the groundwater resources of the study area are all suitable for drinking and other human consumption.

\section{Conclusions and recommendations}

Environmental quality assessment of the groundwater resources of the study area reveals that all are suitable for drinking and for other domestic purposes; all the quality 
Table 9 WQI of groundwater resources of the study area sampled during summer and winter 2012-2013

\begin{tabular}{llllll}
\hline \multirow{2}{*}{ Sample code } & \multicolumn{2}{l}{ Summer } & & \multicolumn{2}{l}{ Winter } \\
\cline { 2 - 3 } \cline { 5 - 6 } & WQI & WQI class & & WQI & WQI class \\
\hline G1 & 73 & Good & & 76 & Good \\
G2 & 80 & Good & & 83 & Good \\
G3 & 68 & Medium & & 79 & Good \\
G4 & 79 & Good & & 82 & Good \\
G5 & 65 & Medium & 70 & Medium \\
G6 & 64 & Medium & 69 & Medium \\
G7 & 70 & Medium & 71 & Good \\
G8 & 79 & Good & & 76 & Good \\
G9 & 69 & Medium & 79 & Good \\
G10 & 68 & Medium & 68 & Medium \\
G11 & 73 & Good & 81 & Good \\
\hline
\end{tabular}

parameters are within the permissible limits set by Omani and WHO standards. However, there are some indications of high nitrate concentrations in some wells, exceeding the limits in Hayl Al Yaman well (2), and not exceeding the limits in Hayl Al Yaman well (1), Al Manakhir well and Sayq well. Overall, the water quality indices are good or medium according to NFS-WQI classification criteria. All groundwater resources are alkaline; major processes controlling water quality are silicate weathering, mineral dissolution and cation exchange. Evaluation of the water types using Piper plot suggests that there is a clear indication of the contribution of the geology of the area from the chemical weathering process of rock formation of mixed calcium and bicarbonate rock types, controlling the major ion composition of groundwater environment. Groundwater is of calcium and bicarbonate type, with some magnesium bicarbonate type; alkaline earth $(\mathrm{Ca}+\mathrm{Mg})$ dominate over alkalis $(\mathrm{Na}+\mathrm{K})$, and weak acids $\left(\mathrm{CO}_{3}+\mathrm{HCO}_{3}\right)$ dominate over strong acids $\left(\mathrm{SO}_{4}+\mathrm{Cl}\right)$; indicating that most of the major ions are natural in origin due to the geology of the region and its effects on the water compositions. Corrective demand management measures, such as water conservation, reuse of treated wastewater effluents, reusing gray water, redesigning septic tanks and expanding sewerage networks, have to be implemented to protect groundwater resources of $\mathrm{Al} \mathrm{Jabal} \mathrm{Al}$ Akhdar. Water quality monitoring programs should be carried out on a regular basis to ensure potable water supplies for human consumption; and more detailed analysis on trace element compositions, microbial investigation and nitrate determination are recommended to further ascertain the quality of groundwater resources in the area.

Acknowledgements The authors would gratefully acknowledge the Public Authority of Electricity and Water, Al Jabal Al Akhdar Office, Oman for their logistic support and permission to sample all groundwater resources in the study area. Our grateful thanks also go to Sultan Qaboos University, Public Authority of Electricity and Water and Ministry of Regional Municipalities and Water Resources, Muscat, Oman for their assistance and facilities provided to analyze the water samples in their laboratories. Finally, we would like to send our greatest appreciations to the Ministry of Environment and Climate Affaires, Muscat, Oman for funding this research.

Open Access This article is distributed under the terms of the Creative Commons Attribution 4.0 International License (http:// creativecommons.org/licenses/by/4.0/), which permits unrestricted use, distribution, and reproduction in any medium, provided you give appropriate credit to the original author(s) and the source, provide a link to the Creative Commons license, and indicate if changes were made.

\section{References}

Adhikary PP, Dash CJ, Chandrasekharan H, Rajput TBS, Dubey SK (2012) Evaluation of groundwater quality for irrigation and drinking using GIS and geostatistics in a peri-urban area of Delhi, India. Arab J Geosci 5(6):1423-1434

Aghazadeh N, Mogaddam AA (2011) Investigation of hydrochemical characteristics of groundwater in the Harzandat aquifer, Northwest of Iran. Environ Monit Assess 176(1-4):183-195

Ahmed M, Victor R, Al Haddabi M, Al-Handali J (2006) Water quality assessment in Al Jabal Al Akhdar Region of Oman for sustainable water resources management. In: Anonymous (eds) Proceedings of the IAESTED international conference on environmentally sound technology in water resources management, ESTW Held September 11-13, 2006 at Gabarone

Alaya MB, Saidi S, Zemni T, Zargouni F (2014) Suitability assessment of deep groundwater for drinking and irrigation use in the Djeffara aquifers (Northern Gabes, south-eastern Tunisia). Environ Earth Sci 71(8):3387-3421

Al-Fahdi AAS (2011) Groundwater exploration study in Al Jabal Al Akhdar area using remote sensing techniques. MSc. in Earth Sciences (Hydrogeology), Department of Earth Sciences, College of Science, Sultan Qaboos University, Muscat

Al-Haddabi LHS (2003) Environmental assessment of an area associated with a diesel contaminated stream in Jebel ALAkhdar, Sultanate of Oman. MSc. in Environmental Sciences, Department of Biology, College of Science, Sultan Qabios University, Muscat

Al-Haddabi LHS, Victor R, Pillay A (2009) Assessment of water quality in a mountain aquatic resource in Al-Jabal Al-Akhdar (Oman) after ten years of diesel contamination. In: Victor R, Robinson MD (eds) Proceedings of the international conference on mountains of the world: ecology, conservation and sustainable development, Held 10-14 February 2008 at Sultan Qaboos University, Muscat. Center for Environmental Studies and Research, Sultan Qaboos University, Muscat, pp 121-126

Al-Harbi M, Al-Ruwaih FM, Alsulaili A (2014) Statistical and analytical evaluation of groundwater quality in Al-Rawdhatain field. Environ Prog Sustain Energy 33(3):895-904

Al-Kalbani MS (2015) Integrated environmental assessment of water resources in Al Jabal Al Akhdar, Sultanate of Oman, using the DPSIR framework, policy analysis and future scenarios for sustainable management. PhD Thesis, University of Aberdeen, Aberdeen

Al-Kalbani MS, Price MF, Abahussain S, Ahmed M, O'Higgins T (2014) Vulnerability assessment of environmental and climate change impacts on water resources in Al Jabal Al Akhdar, Sultanate of Oman. Water (Switzerland) 6(10):3118-3135

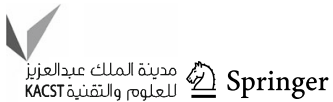


Al-Khashman OA, Jaradat AQ (2014) Assessment of groundwater quality and its suitability for drinking and agricultural uses in arid environment. Stoch Environ Res Risk Assess 28(3):743-753

Al-Marshudi AS (2007) The falaj irrigation system and water allocation markets in Northern Oman. Agric Water Manag 91(1-3):71-77

Al-Mukhtar BM (2013) Development and urbanization in Al Jabal Al Akhdar, Sultanate of Oman. Strateg Vis 100-127

Al-Ujaili SSR (1997) Environmental studies on man-made mountain reservoirs in the Jabal Akhdar area with special reference to water quality. MSc. in Environmental Science, Department of Biology, College of Science, Sultan Qaboos University, Muscat

Aly AA (2014) Hydrochemical characteristics of Egypt western desert oases groundwater. Arab J Geosci. doi:10.1007/s12517014-1680-8

Aly AA, Al-Omran AM, Alharby MM (2014) The water quality index and hydrochemical characterization of groundwater resources in Hafar Albatin, Saudi Arabia. Arab J Geosci 8(6):4177-4190

Anudu GK, Obrike SE, Onuba LN, Ikpokonte AE (2011) Hydrochemical analysis and evaluation of water quality in Angwan Jeba and its environs, Nasarawa State, northcentral Nigeria. Res J Appl Sci 6(2):128-135

APHA (American Public Health Association) (2005) Standard methods for the examination of water and wastewater, 21st edn. American Public Health Association, American Water Works Association and Water Environment Federation Publication, Washington DC

Arumugam K, Rajesh Kumar A, Elangovan K (2014) Assessment of groundwater quality using water quality index in AvinashiTirupur-Palladam Region, Tamil Nadu, India. Int J Appl Eng Res 9(22):12177-12191

Ashura Council (2010) Ashura Council report sent to his majesty Sultan Qaboos Bin said on ways for development of Niyabet Al Jabal Al Akhdar. Ashura Council, Muscat

Ayuba R, Omonona OV, Onwuka OS (2013) Assessment of groundwater quality of Lokoja basement area, North-Central Nigeria. J Geol Soc India 82(4):413-420

Chadha DK (1999) A proposed new diagram for geochemical classification of natural waters and interpretation of chemical data. Hydrogeol J 7(5):431-439

Chapman D (1996) Water quality assessments: a guide to the use of biota, sediments and water in environmental monitoring, 2nd edn. E. \& F.N. Spon, London

Chapman D, Kimstach V (1996) The selection of water quality variables. In: Chapman D (ed) Water quality assessments. E \& FN Spon London, UK, pp 59-126

Chowdhury AK, Gupta S (2011) Evaluation of water quality, hydrogeochemistry of confined and unconfined aquifers and irrigation water quality in Digha Coast of West Bengal, India (a case study). Int J Environ Sci 2(2):576-589

DGMAN (Director General of Meteorology and Air Navigation) (2014) Climatic data: rainfall and temperatures data series [unpublished]. Public Authority of Civil Aviation, Muscat

Doneen LD (1964) Notes on water quality in agriculture. Published as a Water Science and Engineering Paper 4001. Department of Water Science and Engineering, University of California, Davis

Dorvlo ASS, Kwarteng AY, Ampratwum D (2009) Climatic data analysis for sustainable development: Al Jabal Al Akhdar mountain ecosystem, Sultanate of Oman. In: Victor R, Robinson MD (eds) Proceedings of the international conference on mountains of the world: ecology, conservation and sustainable development, Held 10-14 February 2008 at Sultan Qaboos University, Muscat. Center for Environmental Studies and Research, Sultan Qaboos University, Muscat, pp 147-152
Duan L, Sun Y, Wang W (2014) Assessment of regional groundwater quality based on health risk in Xi' an region, P.R. China. Asian J Chem 26(7):1951-1956

El Maghraby MMS, El Nasr AKOA, Hamouda MSA (2013) Quality assessment of groundwater at south Al Madinah Al Munawarah area, Saudi Arabia. Environ Earth Sci 70(4):1525-1538

Ewusi A, Kuma JSY (2014) Groundwater assessment for current and future water demand in the Daka Catchment, Northern Region, Ghana. Nat Resour Res 23(4):355-365

Gibbs RJ (1970) Mechanisms controlling world water chemistry. Science 170(3962):1088-1090

Giriyappanavar BS, Patil RR (2013) Water Quality Assessment of Gullava Reservoir of Belgaum District Usinf NSF-WQI. Int J Sci Res 2(4):71-72

Glennie KW (2005) The geology of the Oman Mountains, an outline of their origin. 2nd ed, Scientific Press Ltd, Beaconsfield, Bucks, $\mathrm{UK}, \mathrm{p} 110$

Glennie KW, Hughes MW, Moody-Stuart M, Pilaar WFH, Reinhadt BM (1974) Geology of the Oman Mountains-part one (text).The Royal Dutch Geological and Mining Society (KNGMG) and Petroleum Development Oman, p 423

González HJD, Carvajal SLF, Toro BFM (2012) Water quality index based on fuzzy logic applied to the Aburra river Basin in the jurisdiction of the metropolitan area. DYNA (Colombia) 79(171):50-58

Gueroui Y, Maoui A, Touati AS (2014) Hydrochemical and bacteriological investigation in groundwater of the Tamlouka Plain, north-east of Algeria. Arab J Geosci. doi:10.1007/s12517014-1393-z

Hanna SS (1995) Field guide to the geology of Oman: Western Hajar Mountains and Musandam, vol 1. The Historical Association of Oman, Muscat, p 178

Huang G, Chen Z, Sun J (2014) Water quality assessment and hydrochemical characteristics of groundwater on the aspect of metals in an old town, Foshan, south China. J Earth Syst Sci 123(1):91-100

Jashoul MSA (2008) Improving quality of Hajamta reservoir water in Jabal Akhdar using a custom-made treatment system. MSc. Thesis in Bioresource and Agricultural Engineering, Department of Soils, Water and Agricultural Engineering, College of Agricultural and Marine Sciences, Sultan Qaboos University, Muscat

Karbassi RA, Mir Mohammad Hosseini F, Baghvand A, Nazariha M (2011) Development of water quality index (WQI) for gorganrood river. Int J Environ Res 5(4):1041-1046

Kata M, Mohan R, Krishna K (2014) Hydrogeochemistry and quality assessment of groundwater around chromite-mineralized areas in India. Environ Earth Sci 74(8):6591. doi:10.1007/s12665-0143479-z

Khashogji MS, El Maghraby MMS (2013) Evaluation of groundwater resources for drinking and agricultural purposes, Abar Al Mashi area, south Al Madinah Al Munawarah City, Saudi Arabia. Arab J Geosci 6(10):3929-3942

Khattak MA, Ahmed N, Qazi MA, Izhar A, Ilyas S, Chaudhary MN, Khan MSA, Iqbal N, Waheed T (2012) Evaluation of ground water quality for irrigation and drinking purposes of the areas adjacent to Hudiara Industrial Drain, Lahore, Pakistan. Pak J Agric Sci 49(4):549-556

Kortatsi BK (2007) Hydrochemical framework of groundwater in the Ankobra Basin, Ghana. Aquat Geochem 13(1):41-74

Kortatsi BK, Anku YSA, Anornu GK (2009) Characterization and appraisal of facets influencing geochemistry of groundwater in the Kulpawn sub-basin of the White Volta Basin, Ghana. Environ Geol 58(6):1349-1359 
Kraiem Z, Zouari K, Chkir N, Agoune A (2014) Geochemical characteristics of arid shallow aquifers in Chott Djerid, southwestern Tunisia. J Hydro Environ Res 8(4):460-473

Kushwaha GJ, Kumar P (2014) Application of Water Quality Index for groundwater quality assessment of Basti City, Utter Pradesh, India. Pollut Res 33(1):105-110

Li R, Merchant JW, Chen X (2014) A geospatial approach for assessing groundwater vulnerability to nitrate contamination in agricultural settings. Water Air Soil Pollut 225:2214. doi:10. 1007/s11270-014-2214-4

MacDonald M (1992) Preparation of water master plans for nine towns. Memorandum Report No. 1 Basic Studies. Ministry of Electricity and Water, Muscat

Magesh NS, Krishnakumar S, Chandrasekar N, Soundranayagam JP (2013) Groundwater quality assessment using WQI and GIS techniques, Dindigul district, Tamil Nadu, India. Arab J Geosci 6(11):4179-4189

Matter JM, Waber HN, Loew S, Matter A (2006) Recharge areas and geochemical evolution of groundwater in an alluvial aquifer system in the Sultanate of Oman. Hydrogeol $\mathrm{J}$ 14(1-2):203-224

MD (2007) Omani Standard 8/2006 for Un-Bottled Drinking Water. Issued by Ministerial Decision (MD 2/2007) dated on 15 January 2007, based on the International Guidelines for Drinking Water Quality vol. 1. Recommendations-World Health Organization. Directorate General for Specifications and Measurements, Ministry of Commerce and Industry, Muscat

Mount VS, Crawford RIS, Bergman SC (1998) Regional structural style of the Central and Southern Oman Mountains: Jebel Akhdar, Saih Hatat, and the Northern Ghaba Basin. GeoArabia 3(4):475-490

MRMWR (2008) Water resources in the Sultanate of Oman. Issued on the occasion of the Expo Zaragoza 2008: water \& sustainable development, 14 June-14 September 2008, Spain. Ministry of Regional Municipalities and Water Resources, Muscat

Nagieb M, Siebert S, Leudeling E, Buerkert A, Häser J (2004) Settlement history of a mountain oasis in Northern Omanevidence from land-use and archaeological studies. Die Erde $135: 81-106$

Nasirian M (2007) A new water quality index for environmental contamination contributed by mineral processing: a case study of amang (tin tailing) processing activity. J Appl Sci 7(20):2977-2987

Nasrabadi T, Abbasi Maedeh P (2014) Groundwater quality assessment in southern parts of Tehran plain, Iran. Environ Earth Sci 71(5):2077-2086

Nazzal Y, Ahmed I, Al-Arifi NSN, Ghrefat H, Zaidi FK, El-Waheidi MM, Batayneh A, Zumlot T (2014) A pragmatic approach to study the groundwater quality suitability for domestic and agricultural usage, Saq aquifer, northwest of Saudi Arabia. Environ Monit Assess 186(8):4655-4667

Piper AM (1944) A graphic procedure in the geochemical interpretation of water analysis. Trans Am Geophys Union 25:914-928

Saber M, Abdelshafy M, Faragallah MEA, Abd-Alla MH (2014) Hydrochemical and bacteriological analyses of groundwater and its suitability for drinking and agricultural uses at Manfalut District, Assuit, Egypt. Arab J Geosci 7:4593-4613. doi:10. 1007/s12517-013-1103-2

Sadashivaiah C, Ramakrishnaiah CR, Ranganna G (2008) Hydrochemical analysis and evaluation of groundwater quality in Tumkur Taluk, Karnataka State, India. Int J Environ Res Public Health 5(3):158-164
Sadat-Noori SM, Ebrahimi K, Liaghat AM (2014) Groundwater quality assessment using the water quality index and GIS in Saveh-Nobaran aquifer, Iran. Environ Earth Sci 71(9):3827-3843

Sajil Kumar PJ (2013) Interpretation of Groundwater chemistry using Piper and Chadha's diagrams: a comparative study from Perambalur Taluk. Elixir Geosci 54:12208-12211

Samanta P, Mukherjee AK, Pal S, Senapati T, Mondal S, Ghosh AR (2013) Major ion chemistry and water quality assessment of waterbodies at Golapbag area under Barddhaman Municipality of Burdwan District, West Bengal, India. Int J Environ Sci 3(6):1938-1956

Sawyer CN (1994) Chemistry for environmental engineering, 4th edn. McGraw-Hill, New York

Sawyer CN (2003) Chemistry for environmental engineering and science, International edn. McGraw-Hill, Boston

Schoeller H (1977) Geochemistry of groundwater. In: UNESCO (ed) Groundwater studies - an international guide for research and practice, Chapter 15. UNESCO, Paris, pp 1-18

Stanger, G. (1986) The hydrogeology of the Oman Mountains. PhD Thesis, vol 2. The Open University, Milton Keynes, p 800

Tatawat RK, Chandel CPS (2008) A hydrochemical profile for assessing the groundwater quality of Jaipur City. Environ Monit Assess 143(1-3):337-343

Todd DK (2005) Groundwater hydrology, 3rd edn. Wiley, New York

Tomar V, Kamra SK, Kumar S, Kumar A, Vishal K (2012) Hydrochemical analysis and evaluation of groundwater quality for irrigation in Karnal District of Haryana State, India. Int $\mathrm{J}$ Environ Sci 3(2):756-766

Tyagi S, Sharma B, Singh P, Dobhal R (2013) Water quality assessment in terms of water quality index. Am J Water Resour 1(3):34-38

USGS (United States Geological Survey) (2014) GW_Chart, a program for creating specialized graphs used in groundwater studies. Version 1.27.0.0. https://www.usgs.gov/. Accessed 14 Apr 2014

Varol S, Davraz A (2015) Evaluation of the groundwater quality with WQI (water quality index) and multivariate analysis: a case study of the Tefenni plain (Burdur/Turkey). Environ Earth Sci 73(4): 1725-1744

Victor R, Al-Ujaili SR (1998) Reservoir limnology in the arid northern mountains of Oman: Problems and prospects. Int Rev Hydrobiol 83(SPEC. ISS.):73-82

Victor R, Al-Ujaili SR (1999) Water quality and management strategies of mountain reservoirs in arid Northern Oman. In: Goosen MFA, Shayya WH (eds) Water management, purification and conservation in arid climates, vol 1. Technomic Publications Co., Inc., Lancaster, pp 307-350

Victor R, Ahmed M, Al Haddabi M, Jashoul M (2009) Water quality assessments and some aspects of water use efficiency in Al Jabal Al Akhdar. In: Victor R, Robinson MD (eds) Proceedings of the international conference on mountains of the world: ecology, conservation and sustainable development, Held 10-14 February 2008 at Sultan Qaboos University, Muscat. Center for Environmental Studies and Research, Sultan Qaboos University, Muscat, pp $165-170$

WHO (World Health Organization) (2011a) Guidelines for drinkingwater quality, 4th edn. World Health Organization, Geneva

WHO (World Health Organization) (2011b) Nitrate and nitrite in drinking-water, Background document for development of WHO Guidelines for Drinking-water Quality. WHO Press, World Health Organization, Geneva 
Wilcox LV (1955) Classification and use of irrigation water. US Department of Agriculture, Washington DC, p 19

WU (Wilkes University) (2014) National Sanitation Foundation Water Quality Index (NSF-WQI). Centre for Environmental Quality, Environmental Engineering \& Earth. http://www. wilkes.edu/. Accessed 14 Apr 2014

\section{Publisher's note}

Springer Nature remains neutral with regard to jurisdictional claims in published maps and institutional affiliations. 